\title{
Romantic Poetry and the Culture of Modernity
}

\section{Citation}

Engell, James. 2001. Romantic Poetry and the Culture of Modernity. Literary Imagination 3(1): 87-98.

\section{Published Version}

http://dx.doi.org/10.1093/litimag/3.1.87

\section{Permanent link}

http://nrs.harvard.edu/urn-3:HUL.InstRepos:2689348

\section{Terms of Use}

This article was downloaded from Harvard University's DASH repository, and is made available under the terms and conditions applicable to Other Posted Material, as set forth at http:// nrs.harvard.edu/urn-3:HUL.InstRepos:dash.current.terms-of-use\#LAA

\section{Share Your Story}

The Harvard community has made this article openly available.

Please share how this access benefits you. Submit a story.

Accessibility 
jengell@fas.harvard.edu

Romantic Poetry and the Culture of Modernity James Engell

Headnote: $\quad$ No account of the origins or essence of the collective cultural phenomena we call "Romanticism" can be adequate. The following does not pretend to be. Since the later nineteenth century, British, French, German, and American critics have attempted to define Romanticism and, more particularly, English Romantic Poetry: as an outgrowth of the French or the American and French Revolutions; as a reaction to the Enlightenment; as an extension of certain aspects of the later Enlightenment (what Isaiah Berlin has called the "Counter-Enlightenment"); as a set of stylistic features and concerns, as political ideology; as essentially conservative, as at bottom liberal; as emotional; as metaphysical; as spiritual; as historically self-conscious in a new way; as incapable of escaping forces of history that are not "romantic"; as itself contradictory, bipolar, and dynamic; and as creating new myths successfully and unsuccessfully. This essay posits as one common denominator the presence--the creation--in English Romantic Poetry of new ideas that specifically respond to and address rapid changes in the nature of knowledge, changes that affect established interrelationships between the arts, the sciences, industry and technology, politics, psychology, language, and history. The best cogent, brief, self-critical account of the construction of various historical accounts of English Romantic Poetry is found in David Perkins, Is Literary History Possible? Chapter 5, "The Construction of English Romantic Poetry as a Literary Classification" (1992). Multiple, current views are collected by Ian McCalman, ed., The Romantic Age: British Culture 1776-1832 (1999). 
"Great spirits" then "on earth" write what we, inadequately, call "romantic poetry"; they respond to a cultural upheaval as deep as any in the history of the West. Yet, in the later 18th century, the word "culture" in its modern sense does not exist in English. Its equivalent, the unifying phrase, "the arts and sciences," is favored by Hume, Goldsmith, and on the Continent. In this upheaval, key shifts disturb the nature of knowledge and the relation between the arts and the sciences. Keats reflects that a "general and gregarious advance of intellect . . . really a grand march of intellect ... a mighty providence subdues the mightiest minds to the service of the time being," an idea Coleridge marks in his Philosophical Lectures as "the gradual Evolution of the Mind of the World, contemplated as a single Mind in the different successive Stages of its development." Why does Keats feel keenly such "a grand march of intellect?" Why does he reflect that while Milton "had sure as great powers," Wordsworth's poetry is now the better model?

In the later 18 th century, western culture stops turning automatically to its classical heritage and gropes awkwardly, at times violently, to establish new modes of knowing, governing, and creating, modes we call modern, democratic, and romantic. An epistemological crisis occurs. Marilyn Butler speaks of it as an epistemological revolution. It challenges the arts, and poetry most of all, because poetry had been regarded, following Aristotle and Sidney, as superior to history and philosophy, uniting the particularity of the former with the universality of the latter, producing texts at once moral, learned, and metaphysical.

Virgil had been used for centuries as a kind of encyclopedia, and Homer had been interpreted according to what Pope describes as his "Allegorical Fable: If we reflect upon those innumerable Knowledges, those Secrets of Nature and Physical Philosophy 
which Homer is generally suppos'd to have wrapt up in his Allegories, what a new and ample Scene of Wonder may this Consideration afford us? How fertile will that Imagination appear, which was able to cloath all the Properties of Elements, the Qualifications of the Mind, the Virtues and Vices, in Forms and Persons; and to introduce them into Actions agreeable to the Nature of the Things they shadow'd?"

Yet new knowledge now arises at an unprecedented rate, its source no longer the ancient world, except for modern scholarship about smaller details of that world. For the first time in the history of the West, writers apply the adjective "accelerating" to the rate at which knowledge is being accumulated. Ancient mythology, often become a stock prop, is, in Johnson's (and Coleridge's) dismissive judgment, "exploded," and early on Wordsworth rejects it. However learned and talented, attempts to revitalize it, such as Akenside's "Hymn to the Naiads," grow feeble. Primitivism provides folk myths from the pagan North and posits societies where poetry still reigns central to all a culture knows and values. Among many, William Duff descants on the apparent connection between the primitive and poetry itself. The last section of his Essay on Original Genius (1767) argues "That original Poetic Genius will in general be displayed in its utmost vigour in the early and uncultivated periods of Society, which are peculiarly favorable to it; and that it will seldom appear in a very high degree in cultivated life." Moreover, views of what constitutes knowledge, truth, reality, psychology, and history now take shape with scant or no connection to classical heritage or primitivism, and with a rapidity never before witnessed. Paul Johnson calls this era the creation of the modern. Emory Neff remarks, the romantics become the classics of the modern world.

And, at that time, starkly put, poetry is threatened by forms of knowledge it does not discover, can not compass, and expresses awkwardly: knowledge in natural philosophy, rapidly maturing from Bacon and Newton into modern experimental science; mathematical relations and a new science of statistics; social and economic theories at 
home in prose; and new philosophy, the nature of which, since Gassendi and Hobbes, seems frankly anti-poetic. (True, Gassendi read Lucretius but chiefly to advance his Epicurean atomism; Hobbes's translation of Homer and his verse autobiography in Latin tend only to confirm the anti-poetic charge.) Locke rejects figurative language. Pascal says Descartes slit the throat of poetry. The whole story is too complicated to get entirely right. But, clearly, modern sciences and mathematics surpass the ancients', who lose that quarrel. In the arts, claims of modern superiority are made, but stronger countervailing voices, such as Hume's, talk of rise and decline. Dryden had remarked in his Defence of the Epilogue that "I profess to have no other ambition . . . than that Poetry may not go backward, when all other Arts and Sciences are advancing." Hazlitt will argue that the arts are not progressive, that the diffusion of culture should never be mistaken for its improvement.

When Alexander Gerard lectures to the Aberdeen Philosophical Society from 1758-69 on the nature of genius, he adds to a prestigious body of work on the nature of achievement and the discovery of knowledge. M.H. Abrams remarks that Gerard's Essay on Genius (1774) "remained for a century the most comprehensive and detailed study devoted . . . to the psychology of the inventive process." In the last part, Gerard considers the nature of imagination "in the two kinds of genius." He employs a broad rubric found in Socrates, Plato, and Aristotle, a pairing reincarnated by C.P. Snow as the "two cultures." But Gerard's division is somewhat different. His two kinds of genius are, first, scientific and philosophic--tellingly, he groups philosophy with science--and, second, artistic. 
All Europe read Gerard's Essay on Genius with enthusiasm. One reader comments on the 1776 German translation: "Gerard, an Englishman, has written about genius, and the treatment he puts forward is the best, although the matter has been discussed by a number of other writers." Kant voices this superlative praise, and will soon echo Gerard's views.

Much could be said about Gerard's work, though little has been. Here we focus on the new distinction he makes between imaginative genius in the arts contrasted to that in the sciences and philosophy. He does not deny that one person may excel in both, but thinks such "flexible" genius highly uncommon. Because genius in science requires increasing specialization and advancement, Gerard implies such flexibility will grow more rare as science amasses knowledge geometrically. His example of James Beattie as uniting art and science--Beattie writes a religio-philosophical Essay on Truth and a poem, The Minstrel, itself exploring genius in art and science--is unconvincing, despite the fact that both works were hugely popular. Also unconvincing is Gerard's example of Hogarth, who treats aesthetics, but not natural, moral, or analytical philosophy, or science.

Gerard is clear about what divides genius in science and philosophy from genius in art. Both employ invention, but genius in science and philosophy evinces "penetration," while in art it exercises "brightness." Science addresses the "understanding," art the external "senses" and "taste." Science and philosophy seek out relation, cause and effect; its genius examines the minute and exact; it desires comprehension and explication; it traces "closely" the nature of things and tries to "fix" their relations. It projects "gravity," "sedateness," and "austerity."

Genius in art adumbrates a final work and will "modify" its constituent parts "intuitively" to shape that whole. Gerard gives the germ for the theory of the work of art as an organic totality. (He also vindicates Coleridge's claim that "intuition" was used 
earlier in English; Reynolds uses it, too, in his Discourses, as does Dryden in $\underline{\text { Heroique }}$ Stanzas.) Genius in art will "hurry" through a "multitude" of images using powers of "suggestion." Fascinated with "resemblance," it displays "sprightliness," "gaiety," "vivacity," and "impetuosity." In art the passions must be aroused; in science they only prejudice "truth." Gerard's division uses the laws of the association of ideas: science and philosophy follow the laws of cause and effect and contiguity; the arts rely more on the law of resemblance. The inference may not be fair, but Gerard makes it.

This may seem trite, but there are deeper consequences. Gerard identifies genius in science and philosophy with "truth and knowledge." He calls this work "important." Art, instead, gives "pleasure" through "beauty," a quality he does not define well. Trying to be even-handed, Gerard undercuts his balance by attributing to genius in art a preoccupation with "adorning" and "ornament," with what he calls, amazingly, the "trivial." Gerard has removed a basis in ideas from the arts; he has weakened their relation to philosophy and, even while praising artistic imagination as subsuming the power of judgment, he aligns it, too, with the older idea of fancy as operating chiefly by visual resemblance.

We can frame this another way. Genius in science and philosophy is important; it has epistemological value; it creates knowledge; it uses concepts and establishes truths; it is solid and penetrating; it progresses and it lasts. Imagination in art can claim not one of these attributes. Its genius produces pleasure through designs and images, ornamenting what is known, appealing to taste through resemblance, through the trivial, and through parts with no real connection outside the inner aesthetic logic of the work of art. Art involves a pleasing cheat, a deception, something escapist as much as recreative. Science and philosophy, on the other hand, own "truth" and "knowledge."

Gerard articulates a crisis of knowledge facing poetry, and also clearly implies that poetry cannot be philosophic. His analysis and others' like his later harden into 
Benthamite utilitarianism, and are reflected by De Quincey's categories of the Literature of Knowledge versus the Literature of Power. But the lines are clearly drawn when Blake is a child. This challenge--a tectonic shift unbalancing the arts and sciences and their human origins, hence a fundamental shift in the content and significance of culture-is answered by a new set of ideas about knowledge, the natural world, and human nature, and that answer is romantic poetry. That poetry is nothing less than a newly posited relation of the arts and sciences, a new culture, a word Wordsworth first uses in its modern sense in the 1805 Prelude.

In Kant's Third Critique, we are struck by how little credit he gives art and poetry in knowing anything, in securing or creating any knowledge. While his critique of aesthetic judgment carries more ethical valence than usually credited, it is vacant of epistemological claims; taste and beauty have only an analogous function to real concepts found in science, morality, philosophy, and reason. Attacks on poetry had assaulted its putative misrepresentation or immorality (e.g., Plato, Gosson), but this, more insidious, is no direct attack; it is a wolf in sheep's clothing. Its praise threatens to make poetry irrelevant in whole realms of value and endeavor. The palace of art becomes love in a hut. The arts exercise passion and pleasure but know nothing; they operate by beauty not truth. Philosophy and science penetrate and reveal; art pleases, period.

No longer, then, any larger unity, the arts and sciences are split, and this threatens to split what is considered culture--and to alienate human nature from it. Every significant romantic poet realizes this challenge, and that realization is largely what separates the work of those poets to whom two centuries of readers constantly return from the work of those eventually less read and less canonized. The response to this challenge brings, at its highest attainments, either joy or irony. Each response belongs to what Keats calls the "authenticity of imagination." 
What we've been discussing is the theme of Keats's great and greatly misunderstood symbolic allegory Lamia. It is a tale "Hard for the non-elect to understand." Keats puts the vision not in the analytical prose of Gerard but in a vocabulary astonishingly identical. The philosopher and scientist Apollonius possesses a serious, grave air. Seeking causes and effects, representing "consequitive reasoning"-which in his famous letter Keats says must hold true as much as does that negative capability necessary for great achievement--the "perceant" eye of Apollonius pierces Lamia and paralyzes her. Lycius, in thrall to her illusions, resemblances, and passions, can only gasp for breath when they are revealed as a serpent's cheat. Lamia vanishes; Lycius dies. The depth of Keats's mind committed to articulating ideas, his honesty as a thinker, and his verbal craft as a poet, together weave a text where he uses sensuous gift of phrase to describe Lamia, yet soon reflects, "There was an awful rainbow once in heaven: / We know her woof, her texture; she is given / In the dull catalogue of common things," the same example Gerard and others use to cite Newton's genius. Lamia's "sciential brain" is used solely "To unperplex bliss from its neighbour pain"; her only awareness is pleasure or passion, what Gerard avowed. Sensuous and sensual, Lamialike figures soon haunt 19th-c art. If Lamia is "knowing," it is in "knowing well / That but a moment's thought is passion's passing bell." Cold science and "Philosophy will clip an angel's wings, / Conquer all mysteries by rule and line, / Empty the haunted air and gnomed mine." Apollonius's eyes are "Keen, cruel, perceant, stinging," and the only thing we have to question their deadly accuracy is Lycius's indictment of them as "juggling," recalling the Latin for "juggler's tricks": "prestidigitation." Lamia calls on the gods to pierce his eyes to blindness with a thorn, but Apollonius survives, his vision 
unimpaired. In different genres, but no less animated by ideas, Margaret Fuller, George Eliot, and Mary Shelley brood on the great debate Keats allegorizes.

Wordsworth in his Preface, in a passage echoed by Coleridge in chapter 14 of the Biographia distinguishes the man of science from the poet. Wordsworth's train of argument is a studied answer to Gerard: "The poet writes under one restriction only, namely, the necessity of giving immediate pleasure ... Nor let this necessity of producing immediate pleasure be considered as a degradation. We have no knowledge, that is, no general principles drawn from the contemplation of particular facts, but what has been built up by pleasure. The Man of science feels that his knowledge is pleasure; and where he has no pleasure he has no knowledge. ... The knowledge both of the Poet and the Man of science is pleasure." The knowledge of the poet "cleaves to us as a necessary part of our existence, our natural and unalienable inheritance" involved with "habitual and direct sympathy connecting us with our fellow-beings." Wordsworth may be taking a cue from Joanna Baillie's "Introductory Discourse to Plays on the Passions," where she dismisses much literature as escapist, fantastic, or merely sentimental, calling all that "nonsense," but she avows that "the highest pleasures we receive from poetry, as well as from the real objects which surround us in the world, are derived from the sympathetick interest we take in beings like ourselves." Without this, she says, in a revealing image that ends her "Discourse," "our remembrance" of all the verbal glories and inventiveness of poetry "would rest upon our minds like the measurement and distances of the planets."

To close his enthymemes on poetry and science, Wordsworth concludes, the poet is the "rock of defence for human nature." Similarly, for Keats, the poet might escape to verbal felicity only, a mere fever of itself; or, like the "human friend philosopher," the poet might instead "lift the thoughts and soothe the cares of humankind." In Germany, it was said that Schelling had again made the world a place for religion, love, and poetry. 
Shelley reasserts the claims of sympathy, love, and knowledge bound together. Poetry "is at once the centre and circumference of knowledge . . . comprehends all science." Poetry creates civil society, culture. Shelley is not answering Gerard, but Peacock, whose attack in The Four Ages of Poetry bears repeating: "Poetry cannot travel out of the regions of . . the uncultivated lands of semi-civilized men.... While the historian and philosopher are advancing in, and accelerating, the progress of knowledge, the poet is wallowing in the rubbish of departed ignorance...." If a poet "can impose" on any "common readers," it is only because "a man who knows something, however little, always possesses [a "commanding advantage"] over one who knows nothing. ... A poet's ideas, thoughts, feelings, associations, are all with barbarous manners.... The march of his intellect is like that of a crab, backward." Peacock's Four Ages may be half tongue-in-cheek, calculated to provoke, and he is not above stealing an image from Hamlet. But he voices a dominant view when he contrasts all that poetry does to "the thinking and studious, and scientific and philosophical part of the community."

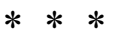

The deep shift in the nature of culture and knowledge, the crisis of poetry, is a matter of utmost concern to those poets we continue to value. We renew our interest in the poetry of sentiment, in part because we realize, with Hume, that sentiment accompanies every idea. But sentiment alone is not an idea, and so the more any poetry is identified as sentiment exclusively, however great its verbal gifts, the more it will fail to address the constant, self-conscious redefinition of human nature in relation to the knowledge it acquires and the new culture it continually creates.

Helen Vendler, in her study of Seamus Heaney, says that the success of lyric has nothing to do with "themes" but everything to do with accuracy of language related to the 
emotions of the speaker. I agree with her about many things but not this. It is a partial truth. Even in lyric, let alone the greater lyric, odes, narrative, and long poems, the verbal gift of phrase--what Arnold calls poetry "as poetry," the success at new combinations of words--cannot be sustained without profound qualities of mind, which in poetry are expressed through images and symbols that convey not emotions only but emotions interfused with ideas. What James Merrill calls "hole-in-one at word golf" is a means but not the complete end of such poetry. Something more is needed to bring "the whole soul of man into activity," to compose, as Coleridge says Wordsworth is capable of composing, "the first genuine philosophic poem." If poetry were simply accuracy of language keyed to emotional states, or to the state of any being or object, "if" this goal, however "fine" and aesthetic it may be, "is the very thing in which consists poetry," muses Keats on this very point, then "it is not so fine a thing as philosophy--For the same reason that an eagle is not so fine a thing as a truth." In a more positive formulation, as Coleridge puts it in a letter, "A great Poet must be, implicitè if not explicitè, a profound Metaphysician." The new ideas expressed by romantic poetry--ideas about language, the soul, history, art, sympathy and the passions, about love, spirituality and the transcendent, about what constitutes culture, the very relation of the arts and the sciences as they inform our inner lives--amount, perhaps, not to the creation of a new human nature, but at the very least to a new articulation of human nature. To use Emerson's pronouncement, "the mind became aware of itself"; and with this freshening self-consciousness, "the best part of human language," Coleridge would contend, "is formed by a voluntary appropriation of fixed symbols to internal acts, to processes and results of imagination." The rules of criticism become the workings of the imagination. The ideas and emotions of significant poetry drawn from this or from any time will always be as vital for the attainment of our wider knowledge--which includes self-knowledge--as is the most technically advanced grasp of reality in the present. So, when we trace the flowing river, 
the history of our humanity, and come to our own personal River Duddon, "We feel that we are greater than we know."

This is no call for poetry as a gussied up paraphrase of pre-cast philosophy, what Randall Jarrell criticizes, rightly or wrongly, in Wallace Stevens, himself so deeply influenced by romantic thought, especially Coleridge's; rather, it recognizes that the language of poetry is inextricably bound up with images, and images with ideas. If we trace the origins of these elusive terms we will find it so. And the ability to create new images and ideas is what makes the best exercise of poetry superior to, not dependent upon, ideology. For ideologies are often nothing more than the hardened cinders left by an extinguished fire of ideas.

At least two related matters present themselves. First, genre: one summit of poetic achievement had been the epic. To compose one, it had been thought since the early Renaissance essential to be learned, to have studied, as Milton did, and as Dryden planned but never did--ten years or more. Romantic poetry rejects such learning in favor of ideas. T.S. Eliot continues to reject such learning for modernist poetry in "Tradition and the Individual Talent": "It will even be affirmed that much learning deadens or perverts poetic sensibility." What is important is not massed knowledge but "consciousness of the past." The epics of Wordsworth and of Byron do not presuppose or evince wide learning but are exquisite in their consciousness of the past. Theirs are poems of personal temperament facing a world where applied knowledge is, more often than not, inhumane. Byron uses it as a foil. "The patent age of new invention," the age of Humphrey Davy's coal lamps and the like, "serve mankind "as true / Perhaps, as shooting them at Waterloo." Poetry that directly expresses the results of science as objective knowledge flares then dies out; the last science to enjoy widespread poetic treatment is geology because it is the least experimental, the most historical, and the most directly connected with landscape. 
Second, the canon: the romantic poets we return to with greatest frequency are those who recognize the signal challenges that new knowledge and new technologies present to us and thus to poetry, and whose work contains, in ideas as well as in language and feeling, a convincing or meaningful response to those challenges, a response that defends the human. These ideas are not happy pieties; some are tied in the hard knot of skepticism, some in the Gordian Knot of irony. Many come in debates, many are doubted. The speed and order of the canonization of these poets is directly correlated to the transparency with which they express their ideas, with Byron and Wordsworth coming first (being so transparent, Byron lost ground during modernism and the New Criticism), followed by Coleridge and Keats, and, if strong critical notice and sympathetic understanding are a measure, with Shelley and Blake last.

We live with constant realignments of the arts and sciences; any culture encompassing them must be in flux. To read Francis Bacon, to chart his intense ambivalence, his admiration yet distrust of figurative language, is to see in embryo this characteristic of modernity. Now we are on the verge of altering our own natures genetically. If we do it well, it will be worthwhile, but the flow of knowledge and its implications for what we mean by human nature continue to accelerate. Romantic poets answer the challenge of humanizing the knowledge we gain, of remaining human in the face of the new powers and new sorrows such knowledge brings. Their obstinate questionings, their poems, are therefore friends to us, but the challenge persists. We hope for great spirits now on earth. Los admonishes us. We stand, like Keats's dreamer--or poet-- in The Fall of Hyperion, at the bottom of the steps, and we are admonished. 